Research Paper

\title{
Synergistic Effects of Curcumin and 5-Fluorouracil on the Hepatocellular Carcinoma In vivo and vitro through regulating the expression of COX-2 and NF-KB
}

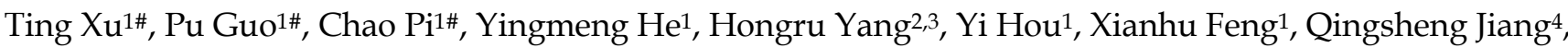 \\ Yumeng Wei ${ }^{{ }^{\bowtie}}{ }^{\bowtie i n g} Z$ hao $^{1 \bowtie}$ \\ 1. Department of Pharmaceutics, School of Pharmacy, Southwest Medical University, No. 319, Zhongshan Rd Sanduan, Jiangyang District,Luzhou, Sichuan, \\ 646000, P.R.China \\ 2. The Affiliated Hospital, Southwest Medical University, No.25, Taiping Street, Luzhou, Sichuan, 646000, China \\ 3. Department of Oncology, Luzhou People's Hospital, No.316, Jiugu Dadao Erduan, Luzhou, Sichuan, 646000, China \\ 4. School of International Education, Southwest Medical University, No.1, Xianglin Rd Yiduan, Longmatan District, Luzhou, Sichuan, 646000, China \\ \#These authors contributed equally to this work.
}

$\triangle$ Corresponding authors: Yumeng Wei, School of Pharmacy, Southwest Medical University, No.319, Zhongshan Road Sanduan, Jiangyang District, Luzhou, Sichuan, 646000, P. R. China. Tel: +86 830 3162291; Fax: +86 830 3162291; E-mail: weiyumeng-268@163.com. Ling Zhao, School of Pharmacy, Southwest Medical University, No.319, Zhongshan Road Sanduan, Jiangyang District, Luzhou, Sichuan, 646000, P. R. China. Tel: +86 8303162292 ; Fax: +86 830 3162292; E-mail: zhaoling-998@163.com

() The author(s). This is an open access article distributed under the terms of the Creative Commons Attribution License (https://creativecommons.org/licenses/by/4.0/). See http://ivyspring.com/terms for full terms and conditions.

Received: 2019.11.04; Accepted: 2020.03.04; Published: 2020.04.06

\begin{abstract}
Curcumin (CU) has shown broad anti-cancer effects. 5-fluorouracil (5-FU) has been a conventional chemotherapeutic agent for hepatocellular carcinoma. Unfortunately, the nonspecific cytotoxicity and multidrug resistance caused by long-term use limited the clinical efficacy of 5-FU. This study was aimed to investigate whether the combination of $\mathrm{CU}$ and 5-FU could generate synergistic effect in inhibiting the human hepatocellular carcinoma. The results of cytotoxicity test showed that compared with applying single drugs, the combination of $\mathrm{CU}$ and 5-FU (1:1, 1:2, 1:4, 2:1 and 4:1, $\mathrm{mol} / \mathrm{mol}$ ) presented stronger cytotoxicity in SMMC-7721, Bel-7402, HepG-2 and MHCC97H cells, while the combination groups are relatively insensitive to normal hepatocytes (L02). Among them, the molar ratio of 2:1 combination group showed strong synergistic effect in SMMC-7721 cells. Then, western blotting assay further verified that the mechanism of the synergistic effect may be related to the inhibition of the expression of NF-KB (overall) and COX-2 protein. In addition, the synergistic effect was also validated in the xenograft mice in vivo. This research not only provides a novel and effective combination strategy for the therapy of hepatocellular carcinoma but also provides an experimental basis for the development of $\mathrm{CU}$ and 5-FU compound preparation.
\end{abstract}

Key words: Curcumin; 5-Fluorouracil; Hepatocellular carcinoma cell lines; COX-2; NF-кB

\section{Introduction}

Hepatocellular carcinoma (HCC) was one of the fifth major common cancers and accounted for $55 \%$ of the cases in the world [1-5]. HCC was easy to metastasize and difficult to diagnose in the early stage $[6,7]$. Furthermore, less than $20 \%$ patients with liver cancer could be treated through surgery [8]. Therefore, systemic chemotherapy became the major therapeutic means to treat liver cancer.
5-Fluorouracil (5-FU) was one of the first-line chemotherapy drugs for the treatment of malignant tumors including liver, breast and other digestive system tumors [9-11]. However, the clinical application of 5-FU was limited due to its inevitable toxicity to normal cells and multidrug resistance caused by long-term use [12, 13]. Recent studies have found that 5-FU combined with natural drug 
monomers can reduce the dose of 5-FU and increase the therapeutic effect, such as CU, sorafenib, huaier, forbesione [14-16]. Among them, curcumin (CU), a natural polyphenol with low toxicity, was extracted from the rhizome of Curcuma longa Linn with a wide range of therapeutic effects especially anti-tumor property [17]. Researches have elucidated that CU suppressed the proliferation of kinds of tumor cells via targeting the signal pathways including COX-2 and NF-kB $[18,19]$.

Recently, many experiments showed that the development of HCC could be inhibited with down-regulation of NF-kB [20, 21]. Ji et al. also found that down-regulation of NF-kB could enhance the sensitivity of cancer cells to 5-FU [22]. NF- $\mathrm{kB}$ bound to IкB kinase (IKK) then composed p50-p65-ІкB tripolymer which made NF-kB in an inactive state in the cytoplasm [23]. When cancer cells were activated by the activators of NF-kB, IKK dissociated and NF- $\mathrm{KB}$ was expressed in heterodimers and translocated from cytoplasm to nucleus, which induced the proliferation, differentiation, apoptosis and malignant metastasis of cancer cells [24]. So, blocking NF-kB translocation from the cytoplasm to the nucleus was a reasonable inhibiting cancer development. COX-2 was associated with the occurrence and development of tumor through a variety of ways such as inhibiting apoptosis and stimulating the growth of tumor cells, etc $[25,26]$. The mechanism of anti-apoptosis associated with anti-apoptotic protein $\mathrm{Bcl}-2$ which can inhibit the release of cytochrome $\mathrm{C}$ from mitochondria in the apoptotic HCC cells [27]. Yang et al. confirmed that COX-2 was overexpression in HCC, and low expression in normal liver tissues [28]. Therefore, these provided a mechanism theoretical basis for the novel combination of $\mathrm{CU}$ and 5-FU to treat HCC in this study.

$\mathrm{CU}$ and 5-FU showed synergetic effect on some cancers such as colon cancer and gastric cancer, which can not only improve the efficacy of 5-FU, but also decrease the concentration of 5-FU, preventing the damage of normal cells $[29,30]$. Although there were some literatures concerning about the combined effects of CU and 5-FU, their research objects or joint proportion were relatively single. In this study, we only focused on the hepatocarcinoma cell lines to study the toxicity of different combinations on different hepatoma cells and screen out the most sensitive cell line (SMMC-7721) and the best proportion (2:1). To further clarify the molecular mechanism of the combination therapy, the expression of COX-2 and NF-kB in SMMC-7721 cells were evaluated by western blotting analysis. And the synergistic effects were also validated in vivo.
Therefore, CU combined with 5-FU is a potential method for HCC treatment in the future.

\section{Materials and methods}

\section{Chemicals and reagents}

CU (purity $\geq 98 \%$ ), 5-FU, RPMI 1640 medium, fetal serum, $0.25 \%$ trypsin, and 100 units $/ \mathrm{mL}$ of penicillin-streptomycin were purchased from Thermofisher Company. MTT (3-(4,5-dimethyl-2thiazolyl)-2,5 diphenyl-2-H-tetrazolium bromide) were purchased from Luzhou Shuangjiang Chemical Co, Ltd (Sichuan, People's Republic of China). CU and 5-FU were dissolved in DMSO (dimethyl sulfoxide) and taken as $800 \mu \mathrm{mol} / \mathrm{L}$ solution with complete culture solution, in which a final concentration of DMSO was $0.1 \%(\mathrm{v} / \mathrm{v})$, and then further diluted as needed in cell culture medium. The NF-кBp65 antibody, COX-2 antibody and $\beta$-actin were purchased from Santa Cruz Company.

\section{Animals and Cell Cultures}

SMMC-7721, Bel-7402, HepG-2, MHCC97H and L02 cells were obtained from Shanghai cell bank of China, and the cells were cultured in RPMI 1640 medium supplemented with 100 units $/ \mathrm{mL}$ of penicillin-streptomycin and $10 \%$ fetal calf serum at $37^{\circ} \mathrm{C}$ in a $5 \% \mathrm{CO} 2$ incubator (HEPA class100 Thermo company). Medium was replaced 3 times a week. Cells were used in the exponential growth phase for all of the experiments.

Female BALB/c nude mice aged four to six weeks (16-20 g) were obtained from Chengdu Dashuo Laboratory Animal Company (Chengdu, China), with the Laboratory Animal License: SCXK (chuan) 2015-030. The animals were fed in the IVC Animal Feeding Room of the Laboratory Animal Center of Southwest Medical University at temperature of $20 \pm$ $2^{\circ} \mathrm{C}$, with relative humidity of $40-60 \%$. All studies on nude mice were approved by the Committee on the Ethics of Animal Experiments of the Southwest Medical University, Luzhou, People's Republic of China (No 2015DW040).

\section{Cell inhibition assay}

To examine the inhibition effect of compound preparation of CU and 5-FU on HCC, SMMC-7721, Bel-7402, HepG-2, MHCC97H and L02 cells were inoculated into 96 -well plates at the density of $5 \times 10^{3}$ cells/well $/ 100 \mu \mathrm{L}$, respectively. After being cultured for $24 \mathrm{~h}$ at $37^{\circ} \mathrm{C}$ with $5 \% \mathrm{CO} 2$, CU solution $(6.25,12.5$, 25.00, 50.00, 100.00 and $200.00 \mu \mathrm{mol} / \mathrm{L}), 5-\mathrm{FU}$ solution $(6.25,12.5,25.0,50.0,100.0$ and $200 \mu \mathrm{mol} / \mathrm{L})$ and different combination groups of $\mathrm{CU}$ and 5-FU with the mole ratio of 1:1, 1:2, 2:1, 1:4, 4:1 were added to the 96-well plates with gradient concentrations and 
incubated for $48 \mathrm{~h}$, respectively. Dimethyl sulfoxide (DMSO) was used as the solvent to prepare drug substances solutions and the same volume of solvent was considered as vehicle control. Then, $20 \mu \mathrm{L}$ of MTT $(5 \mathrm{mg} / \mathrm{mL}$ ) were added to each well and the cells were incubated for another $4 \mathrm{~h}$ at $37^{\circ} \mathrm{C}$ in the dark. The aliquots were removed and the remaining crystals (formazan precipitates) were solubilized with $150 \mu \mathrm{L}$ of DMSO and the cells were incubated for an additional $10 \mathrm{~min}$ at $37^{\circ} \mathrm{C}$ with gentle shaking before the measurement of the absorbance (OD) at $490 \mathrm{~nm}$ using an enzyme-linked immunosorbent assay. All the samples were performed in triplicate.

The tumor cell inhibitory rate was calculated as follows. Inhibitory rate $(\%)=(\mathrm{OD}$ control - OD treated) / OD control $\times 100 \%$. The $\mathrm{IC}_{50}$ (half maximal inhibitory concentration) values of the drugs were calculated by SPSS 18.0 software (IBM SPSS Statistics, Chicago, IL, USA).

\section{Examination of the Effects of Combination Agents}

The median effect method was used to estimate the combination effects of the two drugs. Before the combination effect was tested, the $\mathrm{IC}_{50}$ (the half maximal inhibitory concentration) was determined from the exposure of the drugs including single agent and the combination agents to the HCC cells by MTT assay. And then the combination index (CI) was calculated by the following formula [31]:

$$
C I=\frac{(D)_{1}}{\left(D_{x}\right)_{1}}+\frac{(D)_{2}}{\left(D_{x}\right)_{2}}+a \frac{(D)_{1}(D)_{2}}{\left(D_{x}\right)_{1}\left(D_{x}\right)_{2}}
$$

In this equation, (D) 1 and $(D)_{2}$ values were combined drug concentrations of $\mathrm{CU}$ and 5-FU, respectively, resulting in growth inhibition of the HCC (SMMC-7721 and Bel-7402) cell lines (in $x \%$ ). $\left(D_{x}\right)_{1}$ and $\left(D_{x}\right)_{2}$ were the concentrations of $C U$ and 5-FU alone that inhibited the cells growth at the same percentage $(\mathrm{x})$. CI indicated synergism $(\mathrm{CI}<1)$, summation $(\mathrm{CI}=1)$ or antagonism $(\mathrm{CI}>1)$ of the two drugs, respectively. $\left(D_{\times}\right)_{1}$ and $\left(D_{\times}\right)_{2}$ can be obtained from the following formula:

$$
D_{x}=D_{m}\left[f_{a} /\left(1-f_{a}\right)\right]^{1 / m}
$$

Among them, $D_{m}$ was the median-effect dose, $f_{a}$ was the fraction affected, and $m$ was the slope of the median-effect plot.

\section{The mechanism of synergism effect of the combination of $\mathrm{CU}$ and 5-FU}

The test was divided into eight groups including group one: curcumin alone $(25 \mu \mathrm{mol} / \mathrm{L})$; group two: vehicle control (RPMI1640 medium containing same concentration of DMSO); group three: 5-FU alone (15 $\mu \mathrm{mol} / \mathrm{L})$; group four: $2.5 \mu \mathrm{mol} / \mathrm{L} \mathrm{CU}+5 \mu \mathrm{mol} / \mathrm{L}$ 5 -FU; group five: $5 \mu \mathrm{mol} / \mathrm{L} \mathrm{CU}+2.5 \mu \mathrm{mol} / \mathrm{L} \mathrm{5-FU;}$ group six: $5 \mu \mathrm{mol} / \mathrm{L} \mathrm{CU}+5 \mu \mathrm{mol} / \mathrm{L} 5-\mathrm{FU}$; group seven: $5 \mu \mathrm{mol} / \mathrm{L} \mathrm{CU}+10 \mu \mathrm{mol} / \mathrm{L} 5-\mathrm{FU}$; group eight: $10 \mu \mathrm{mol} / \mathrm{L} \mathrm{CU}+5 \mu \mathrm{mol} / \mathrm{L}$ 5-FU. Then, SMMC-7721 cells (up to the density of $90 \%$ ) were seeded at $1 \times 10^{6}$ cells into $10 \mathrm{~cm}^{2}$ petri dishes, then, incubated for $24 \mathrm{~h}$ and treated with drugs of above eight groups for $48 \mathrm{~h}$, respectively. Then, the culture media were discarded and the cells were washed with cold PBS buffer twice for harvest. Cell pellets were disrupted in cell RIPA buffer and collected after centrifuging at $16000 \times \mathrm{g}$ for $10 \mathrm{~min}$ at $4^{\circ} \mathrm{C}$, and the lysates were centrifuged at $15000 \times \mathrm{g}$ for $10 \mathrm{~min}$ at $4^{\circ} \mathrm{C}$ to collect the cytoplasmic and nuclear proteins, respectively. The protein concentrations were determined by phenyl methane sulfonyl fluoride (PMSF) method. Protein samples (30 $\mu \mathrm{L}$ each) were loaded on SDS-PAGE (sodium dodecyl sulfate- polyacrylamide gels) and separated with electrophoresis and subsequently transferred onto NC membranes. Non-specific binding was blocked with $5 \%$ milk in TBST $(5 \mathrm{mmol} / \mathrm{L}$ Tris- $\mathrm{HCl}, 136 \mathrm{mmol} / \mathrm{L}$ $\mathrm{NaCl}$, and $0.05 \%$ Tween-20, $\mathrm{pH} 7.6$ ) for $1 \mathrm{~h}$. The membranes were cultured with primary antibodies against COX-2 (1:1000), NF-Kbp65 (1:15000) or $\beta$-actin (1:2000) overnight at $4^{\circ} \mathrm{C}$. Then the membranes were washed three times with $1 \times$ TBST, followed by incubating with secondary antibodies (1:1000 dilution) at room temperature for $2 \mathrm{~h}$ and washed three times with $1 \times$ TBST. Protein bands were visualized by an ECL (enhanced chemiluminescence) system (Amersham Biosciences, the United States). The grey value of NF-kB, COX-2 and $\beta$-actin proteins was measured by the Quantity One software.

\section{In vivo antitumor study}

\section{Construction of tumor model}

SMMC-7721 cells were harvested (with trypsinase) and suspended in the cell solution containing PBS buffer and Matrigel $(1: 1, \mathrm{v} / \mathrm{v})$ to reach $2.5 \times 10^{7}$ cells $/ \mathrm{mL}$, when the cells were in logarithmic growth phase. $0.2 \mathrm{~mL}$ cell suspension $\left(5 \times 10^{6}\right.$ cells $/ \mathrm{mL}$ ) was injected subcutaneously into the right forelimb of nude mice sterilized with $75 \%$ alcohol and fed in the SPF animal room. Tumor volume (V) was measured with a vernier caliper using the formula: $\mathrm{V}$ $=0.5 \times \mathrm{a} \times \mathrm{b}^{2}$. a was the maximum perpendicular diameter, and $\mathrm{b}$ was the minimum perpendicular diameter. When tumor volume reached $70-120 \mathrm{~mm}^{3}$, mouse models were selected for subsequent experiments. 


\section{Pharmacodynamics studies}

Twenty tumor-bearing mice were randomly divided into four groups with 5 mice in each group. Negative control group: blank solvents including polyoxyethylene castor oil EL-35: absolute ethanol: $0.9 \%$ sodium chloride injection $(1: 1: 6, \mathrm{v} / \mathrm{v} / \mathrm{v})$; CU group: CU (56.65 mg/kg); 5-FU group: 5-FU (10 $\mathrm{mg} / \mathrm{kg})$; CU/5-FU group: CU $(56.65 \mathrm{mg} / \mathrm{kg})+5-\mathrm{FU}$ $(10 \mathrm{mg} / \mathrm{kg})$. All groups were injected with $0.2 \mathrm{~mL}$ injection by intraperitoneal injection. The total treatment cycle was 29 days with the frequency of twice a week. After inoculation, tumor-bearing mice were fed and drank water freely. The diet, mental state and activities of tumor-bearing mice were observed daily. The weight of tumor-bearing mice in each group was weighed every 3 days, and the tumor volume was measured with vernier caliper.

After $48 \mathrm{~h}$ of the last administration, the tumor-bearing mice were sacrificed, and the tumors were removed completely. The tumor inhibition rate was calculated by weighing the tumors with an electronic balance. Tumor inhibition rate (\%) = (average tumor weight of control group - average tumor weight of drug group) / average tumor weight of control group $\times 100 \%$ [32].

\section{Statistical analysis}

Each experiment was performed for quintuple. Statistical data were conducted using SPSS 19.0, and summarized as means \pm SD (standard deviation). The comparison between group using one-way ANOVA and Tukey test, and P-value less than 0.05 were considered statistically significant.

\section{Results}

\section{Antiproliferative effects of combination group of $\mathrm{CU}$ and 5 -FU}

In MTT assay, SMMC-7721, Bel-7402, HepG-2, MHCC $97 \mathrm{H}$ and L02 cells were administrated with different concentrations of $\mathrm{CU}$ and 5-FU alone or in combination $(1: 1,1: 2,1: 4,2: 1$ and $4: 1, \mathrm{~mol} / \mathrm{mol})$ for 48 $h$, respectively. In our preliminary study, the cytotoxicities of the negative control ( $2 \%$ DMSO) did not cause significant cytotoxicity against above cell lines up to the highest dose of $200 \mu \mathrm{mol} / \mathrm{L}$. All the cell viabilities were greater than $90 \%$ after incubating with $2 \%$ DMSO for $48 \mathrm{~h}$ (data were not shown). MTT results (Figure 1 and Table 1) showed that the growth of five kinds of cell lines were inhibited by the treatment of $\mathrm{CU}$ and 5-FU alone or in combinations. The cytotoxicity of all combined groups in the researched hepatoma cell lines was better than that of $\mathrm{CU}$ or 5-FU alone, except the combination group of 1:4 in SMMC-7721 and HepG-2 cells. Interestingly, Figure $1 \mathrm{~A}-1 \mathrm{~B}$ also showed that each combination ratio has stronger selectivity to SMMC-7721 than other three hepatoma cell lines. Furthermore, the $\mathrm{IC}_{50}$ of $2: 1$ group in SMMC-7721 cells was the least among all combination groups and cell lines. Specifically, the $\mathrm{IC}_{50}$ value of $\mathrm{CU}$ in $2: 1$ group was $4.32 \pm 2.02 \mu \mathrm{mol} / \mathrm{L}$ and that of 5-FU in 2:1 group was $2.16 \pm 1.05 \mu \mathrm{mol} / \mathrm{L}$. Besides, compared with the toxic effect on hepatoma cells, normal liver cells line was relatively resistant to the combined treatment of CU and 5-FU with 1:1, 1:4 and 2:1 ratio. Then, the 2:1 group could selectively increase the cytotoxicity to SMMC-7721 cells. Therefore, we chose 7721 and 2:1 ratio as our subsequent research object.

Table 1: The $\mathrm{IC}_{50}$ values of $\mathrm{CU}$ and $5-\mathrm{FU}$ alone and in combination in L02, SMMC-7721, Bel-7402, HepG-2 and MHCC97H cells for $48 \mathrm{~h}$.

\begin{tabular}{|c|c|c|c|c|c|c|}
\hline \multirow{2}{*}{$\begin{array}{l}\mathrm{CU} / 5-\mathrm{FU} \\
(\mathrm{mol} / \mathrm{mol})\end{array}$} & \multirow[t]{2}{*}{ Drugs } & \multicolumn{5}{|c|}{$\mathrm{IC}_{50}(\mu \mathrm{mol} / \mathrm{L})$} \\
\hline & & L02 & $\begin{array}{l}\text { SMMC-77 } \\
21\end{array}$ & Bel-7402 & HepG-2 & $\begin{array}{l}\text { MHCC97 } \\
\mathrm{H}\end{array}$ \\
\hline \multirow[t]{2}{*}{ 1:01 } & $\mathrm{CU}$ & $\begin{array}{l}34.08 \pm \\
2.36\end{array}$ & $4.95 \pm 1.20$ & $\begin{array}{l}19.30 \pm \\
2.29\end{array}$ & $\begin{array}{l}25.00 \pm 1.2 \\
1\end{array}$ & $\begin{array}{l}35.35 \pm \\
2.84\end{array}$ \\
\hline & 5-FU & $\begin{array}{l}34.08 \pm \\
2.36\end{array}$ & $4.95 \pm 1.20$ & $\begin{array}{l}19.30 \pm \\
2.29\end{array}$ & $\begin{array}{l}25.00 \pm 1.2 \\
1\end{array}$ & $\begin{array}{l}35.35 \pm \\
2.84\end{array}$ \\
\hline \multirow[t]{2}{*}{ 1:02 } & $\mathrm{CU}$ & $\begin{array}{l}15.06 \pm \\
0.66\end{array}$ & $2.49 \pm 0.58$ & $\begin{array}{l}16.15 \pm \\
2.01\end{array}$ & $\begin{array}{l}27.34 \pm 1.7 \\
2\end{array}$ & $\begin{array}{l}16.04 \pm \\
1.12\end{array}$ \\
\hline & $5-\mathrm{FU}$ & $\begin{array}{l}30.12 \pm \\
1.32\end{array}$ & $4.93 \pm 1.17$ & $\begin{array}{l}32.3 \pm \\
4.02\end{array}$ & $\begin{array}{l}54.68 \pm 3.4 \\
5\end{array}$ & $\begin{array}{l}32.07 \pm \\
2.25\end{array}$ \\
\hline \multirow[t]{2}{*}{ 1:04 } & $\mathrm{CU}$ & $\begin{array}{l}32.1 \pm \\
1.46\end{array}$ & $6.15 \pm 1.10$ & $\begin{array}{l}7.63 \pm \\
1.31\end{array}$ & $\begin{array}{l}31.07 \pm 0.8 \\
4\end{array}$ & $\begin{array}{l}22.09 \pm \\
1.19\end{array}$ \\
\hline & $5-\mathrm{FU}$ & $\begin{array}{l}128.4 \pm \\
5.83\end{array}$ & $\begin{array}{l}24.60 \pm \\
4.40\end{array}$ & $\begin{array}{l}30.52 \pm \\
5.24\end{array}$ & $\begin{array}{l}124.27 \pm 3 \\
37\end{array}$ & $\begin{array}{l}88.36 \pm \\
4.77\end{array}$ \\
\hline \multirow[t]{2}{*}{ 2:01 } & $\mathrm{CU}$ & $\begin{array}{l}26.45 \pm \\
1.92\end{array}$ & $4.32 \pm 2.02$ & $\begin{array}{l}45.60 \pm \\
2.56\end{array}$ & $\begin{array}{l}10.36 \pm 1.7 \\
7\end{array}$ & $\begin{array}{l}14.48 \pm \\
1.26\end{array}$ \\
\hline & $5-\mathrm{FU}$ & $\begin{array}{l}13.23 \pm \\
0.96\end{array}$ & $2.16 \pm 1.05$ & $\begin{array}{l}22.80 \pm \\
1.78\end{array}$ & $5.17 \pm 0.88$ & $\begin{array}{l}7.24 \pm \\
0.63\end{array}$ \\
\hline \multirow[t]{2}{*}{ 4:01 } & $\mathrm{CU}$ & $\begin{array}{l}9.33 \pm \\
0.81\end{array}$ & $\begin{array}{l}17.72 \pm \\
4.68\end{array}$ & $\begin{array}{l}17.72 \pm \\
3.88\end{array}$ & $\begin{array}{l}23.59 \pm 4.5 \\
1\end{array}$ & $\begin{array}{l}25.78 \pm \\
2.58\end{array}$ \\
\hline & $5-\mathrm{FU}$ & $\begin{array}{l}2.33 \pm \\
0.20\end{array}$ & $4.28 \pm 1.17$ & $\begin{array}{l}4.43 \pm \\
0.97\end{array}$ & $5.90 \pm 1.13$ & $\begin{array}{l}6.44 \pm \\
0.64\end{array}$ \\
\hline \multirow[t]{2}{*}{ - } & $\begin{array}{l}\text { CU } \\
\text { alone }\end{array}$ & $\begin{array}{l}22.46 \pm \\
2.69\end{array}$ & $\begin{array}{l}89.06 \pm \\
11.85\end{array}$ & $\begin{array}{l}94.74 \pm \\
4.03\end{array}$ & $\begin{array}{l}43.46 \pm 5.3 \\
4\end{array}$ & $\begin{array}{l}65.27 \pm \\
2.22\end{array}$ \\
\hline & $\begin{array}{l}5-\mathrm{FU} \\
\text { alone }\end{array}$ & $\begin{array}{l}32.98 \pm \\
1.23\end{array}$ & $\begin{array}{l}21.90 \pm \\
1.54\end{array}$ & $\begin{array}{l}38.48 \pm \\
2.27\end{array}$ & $\begin{array}{l}40.18 \pm 6.2 \\
4\end{array}$ & $\begin{array}{l}43.86 \pm \\
1.99\end{array}$ \\
\hline
\end{tabular}

\section{Combination effects of different proportion of CU and 5-FU in cells}

As shown in Figure 2 and Table 2, except that the 1:4 group $(\mathrm{CI}>1)$ produced antaonistic effect, most combination groups showed strong synergistic effect in 7721 cells $(\mathrm{CI}<0.3)$, and the 2:1 group showed the strongest synergistic effect among all cell lines. In 7402 cells, the majority combined groups showed moderate synergistic effect $(0.3<\mathrm{CI}<1)$. In HepG-2 cells, except for the antagonistic effect in the 1:1 and 1:4 groups, the other combined groups showed synergistic effect. In MHCC97H cells, except the 1:1, 1:2 and 1:4 groups, the other ratios showed synergistic effects. These data showed that the combination of CU and 5-FU (2:1, $\mathrm{mol} / \mathrm{mol})$ in 7721 showed the strongest synergistic inhibitory effect in all cell lines. Therefore, the 2:1 combination group and 7721 cell line were chosen as follow-up studies. 

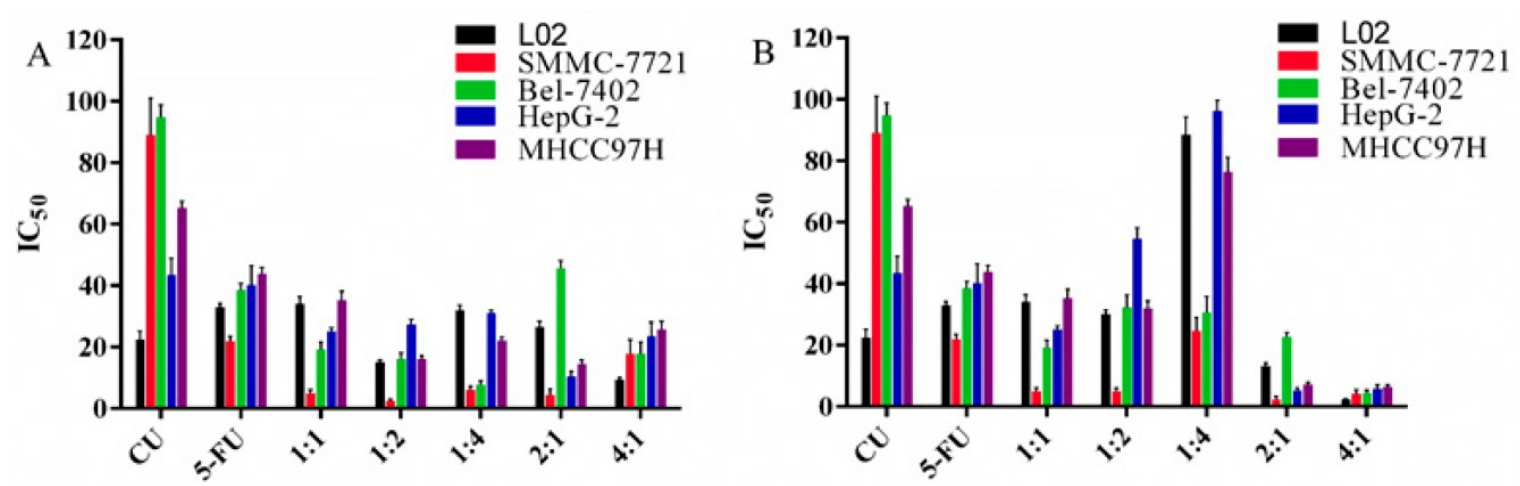

Figure 1. The IC $\mathrm{I}_{50}$ value of each groups of drugs on hepatocarcinoma cells. A: The IC 50 value of $\mathrm{CU}$ in each group and cell lines. B: The IC 50 value of 5 -FU in each group and cell lines.

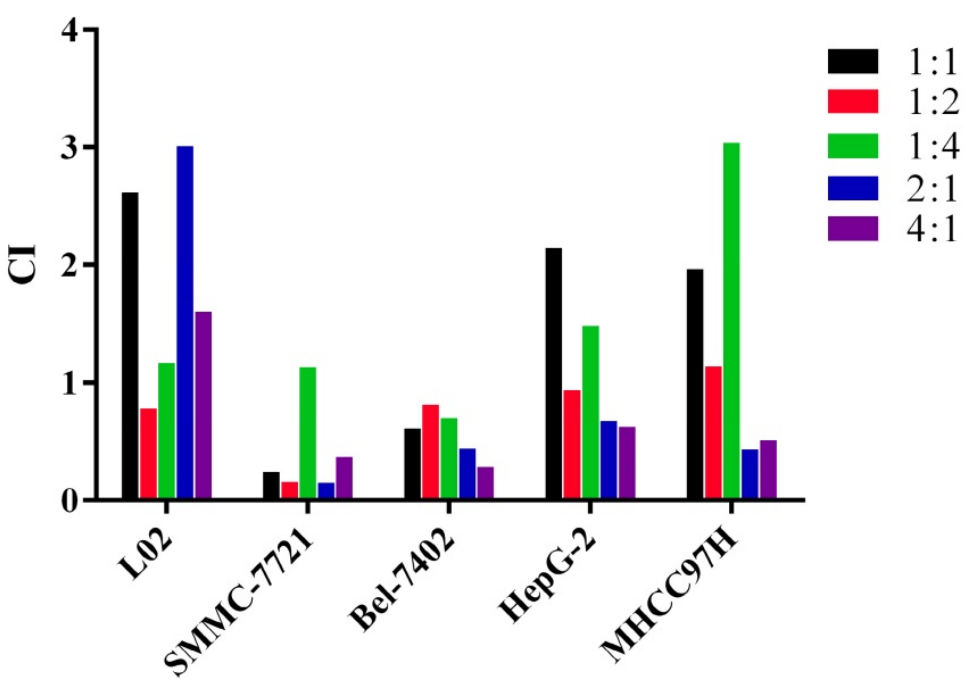

Figure 2. The combination effects $(\mathrm{Cl})$ of $\mathrm{CU}$ and 5 - $\mathrm{FU}$ concurrently exposed to the $\mathrm{HCC}$ cell lines for $48 \mathrm{~h}$. The $\mathrm{Cl}$ values were calculated by the method mentioned above. When $\mathrm{Cl}<1, \mathrm{Cl}=1$ or $\mathrm{Cl}>1$, it indicates synergism, summation or antagonism effect of the two drugs, respectively.

Table 2. The $\mathrm{Cl}$ values of $\mathrm{CU}$ and 5-FU alone and in combination in cells for $48 \mathrm{~h}$.

\begin{tabular}{llllll}
\hline \multirow{2}{*}{ CU/5-FU (mol/mol) } & Cell lines \\
\cline { 2 - 6 } & L02 & SMMC-7721 & Bel-7402 & HepG-2 & MHCC97H \\
\hline $1: 1$ & 2.62 & 0.24004 & 0.60773 & 2.14 & 1.96 \\
$1: 2$ & 0.78 & 0.15843 & 0.81156 & 0.94 & 1.14 \\
$1: 4$ & 1.17 & 1.1316 & 0.69721 & 1.48 & 3.04 \\
$2: 1$ & 3.01 & 0.14698 & 0.43735 & 0.67 & 0.43 \\
$4: 1$ & 1.6 & 0.36951 & 0.285 & 0.62 & 0.51 \\
\hline
\end{tabular}

\section{Influence of different combination groups on SMMC-7721 cells}

In order to better understand the combined effect of CU and 5-FU in SMMC-7721 cells, a line chart of cell inhibition rate varied with proportion of $\mathrm{CU}$ and 5-FU was made with the constant concentration of $\mathrm{CU}$ or 5-FU. As shown in Figure $3 \mathrm{~B}$ when the concentration of 5-FU was remained, at the same concentration of 5-FU, the inhibition rate of each combination was better than 5-FU single group except 1:4 combined group. Furthermore, when 5-FU was in high concentration $(50-100 \mu \mathrm{mol} / \mathrm{L})$, the cell inhibition effect was increased with the increase proportion of CU, especially 2:1 and 4:1 groups. When 5 -FU was in medium concentration $(12.5-25 \mu \mathrm{mol} / \mathrm{L})$, the inhibition effect on SMMC-7721 cells decreased first and then increased with the increase proportion of CU. Among them, 2:1 group was the most effective. When 5-FU was at low concentration $(6.25 \mu \mathrm{mol} / \mathrm{L})$, the inhibitory effect of all combined groups was better than that of 5-FU single group. Interestingly, the combination of 2:1 showed a good inhibitory effect on SMMC-7721 cells whether in low, medium or high concentration stages. The results showed that, to a certain extent, combined with $\mathrm{CU}$, the anti-cancer effect of 5-FU could be promoted.

As shown in Figure 3A, the inhibitory effect of all combination groups was stronger than $\mathrm{CU}$ single group, which suggested that 5-FU combined with CU could increase the anti-cancer effect of CU. Concretely, when $\mathrm{CU}$ was at medium and high concentration (25-200 $\mu \mathrm{mol} / \mathrm{L})$, all the combination regimens exhibited high inhibiting activity on cell apoptosis. When the concentration of CU was less than $25 \mu \mathrm{mol} / \mathrm{L}, 1: 2$ group exhibited the strongest cell inhibition rate in SMMC-7721 cells. 

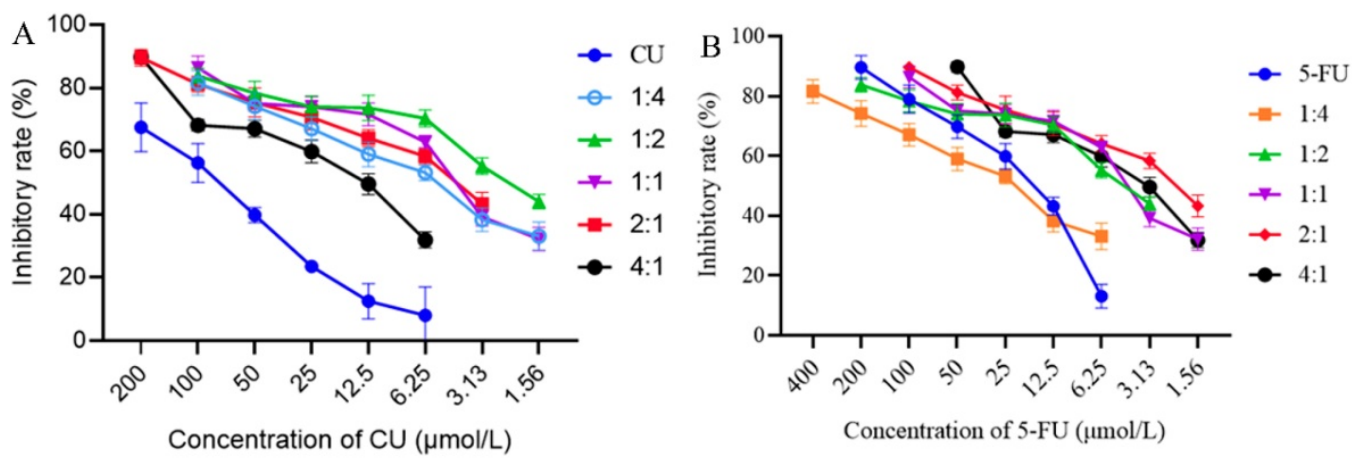

Figure 3. Variety of inhibition rate of combination groups in SMMC-7721 cells with the same concentration of CU (A) or 5-FU (B) after treated with 48 h. Data were expressed as means $\pm S D(n=3)$

In a word, the study was focus on new combination strategy to enhance anti-cancer effect of 5-FU. From the above results, the anti-cancer effect of 5 -FU in SMMC-7721 cells could be enhanced by CU in a range of proportions. More concretely, 2:1 group showed the best synergy effect. So, the combination of $\mathrm{CU}$ and 5-FU with molar ratio of 2:1 and SMMC-7721 cells would be selected to further research the cell mechanism in vitro and pharmacodynamics in vivo.

\section{The mechanism of synergistic effect of joint group.}

The mechanism of SMMC-7721 cells inhibited by $\mathrm{CU}$ and 5-FU alone or combination was unclear. Therefore, western blotting analysis was used to detect the expression and variation trend of COX-2, the nucleus and cytoplasm NF-KB protein extracted from the total cell protein of SMMC-7721 cells. The results were shown in Figure 4. The intensities of protein bands of $\beta$-actin, COX-2, NF-KB in nucleus and cytoplasm are shown in Figure 4A. Compared with the blank group (Figure 4B), the expression of nucleus NF- $\mathrm{kB}$ protein was decreased while the cytoplasm NF-kB protein expression was increased after treated with the combination of $\mathrm{CU}$ and 5-FU for $48 \mathrm{~h}$. The expression of nucleus NF-kB in blank group was higher than that in the single or combination groups. And the cytoplasm NF-kB expression in each combination group was higher than that in the 5-FU group except 1:2 group in high concentration and 1:1 group. Furthermore, the cytoplasm NF-kB expression of 2:1 group $(\mathrm{mol} / \mathrm{mol})$ was the highest. And the nuclear NF-kB expression of 2:1 group (mol/ $\mathrm{mol}$ ) was the lowest in all combination groups. On the one hand, as seen in Figure 4B, with the increase concentration of 5-FU (CU maintained at $5 \mu \mathrm{mol} / \mathrm{L}$ ), the molar ratio of $\mathrm{CU}$ and 5-FU varied from 2:1 to 1:2, the expression of NF- $\mathrm{kB}$ protein in nuclear and cytoplasm increased. On the other hand, with the increase concentration of $\mathrm{CU}$ (5-FU maintained at 5 $\mu \mathrm{mol} / \mathrm{L})$, the molar ratio of $\mathrm{CU}$ and 5-FU varied from
1:2 to 2:1, the expression of nuclear NF- $\mathrm{KB}$ protein increased first and then decreased. However, the expression of cytoplasm NF- $\mathrm{kB}$ protein showed reverse rule. Thus, the combination of $\mathrm{CU}$ and 5-FU $(2: 1, \mathrm{~mol} / \mathrm{mol})$ showed great efficacy of inhibiting the transfer of NF-kB from cytoplasm to nucleus, especially CU: 5-FU (10/5) group.

As for COX-2 protein, it was shown that compared with control group, the COX-2 protein expression was down-regulated in all drug groups except 5-FU alone group. Simultaneously, the effect of down-regulating COX-2 protein in all combined groups was better than that in single groups. Among them, CU/5-FU (2:1) group in high concentration showed the best effect. Namely, at high concentration group, the expression of COX-2 in CU/5-FU (2:1) group was 2.3 folds lower than that in blank group, 2.2-2.5 folds lower than that in single group and 1.4-2.1 folds lower than that in other combined groups. At low concentration group, the expression of COX-2 in CU/5-FU (2:1) group was about 1.5 times lower than other groups. So, no matter in high or low concentration, 2:1 (mol/mol) group showed excellent advantages in inhibiting COX-2 expression.

Therefore, the mechanism of the inhibition efficacy of CU and 5-FU combination $(2: 1, \mathrm{~mol} / \mathrm{mol})$ on the proliferation of HCC cells may be related to inhibiting the transfer of NF-kB from cytoplasm to nucleus and down-regulation of COX-2 protein. However, its specific signal transduction pathway needed further study.

\section{In vivo antitumor study}

During the experiment, the tumor-bearing mice in each group were in good mental state, and their diet and activities were normal. The changes of the body weight of mice, the volume of subcutaneous tumors, the tumors weight and the rate of inhibition of tumors were described in Figure 5A-5D, respectively. Figure 5A showed that the weight of nude mice in each group increased slightly before and 
after administration, and there was no significant difference between the administration group and the negative control group. Figures $5 \mathrm{~B}$ and $5 \mathrm{C}$ showed that the growth of tumor in the negative control group was the most obvious. Compared with the negative control group, the growth of tumors in the other three groups tended to slow down, and the growth of tumors in CU/5-FU group was the slowest, which showed that the inhibitory effect of combined group on tumor growth was more obvious than that of single group. Figure 5D showed that compared with negative control group, all the other three groups had the effect of inhibiting the growth of tumors. The order of inhibition intensity was CU/5-FU> CU> 5 -FU group. The results of the study in vivo indicated that the combination of CU and 5-FU (2:1, $\mathrm{mol} / \mathrm{mol})$ had synergistic effect on inhibiting the tumor growth of SMMC-7721-bearing mice, which verified the conclusion of cytotoxicity study.

\section{Discussion}

Hepatocellular carcinoma (HCC) is the most common primary liver cancer with poor prognosis. However, the treatment options for advanced HCC are very limited. 5-FU-based chemotherapy was widely used for the treatment of HCC. However, the drug resistance and high toxicity limited the efficacy of 5-FU [33, 34]. Therefore, it is necessary to find more effective chemotherapeutic drugs and/or combination therapy for HCC. At present, CU was widely researched due to its characteristics including inducing cell apoptosis, inhibiting tumor invasion and metastasis, reversing tumor resistance, etc [35]. Yu et al. found that the growth of SMMC-7721 cells could be resisted by $\mathrm{CU}$, which was due to inhibiting the Bcl-2 and activate Bax protein and promote caspase 3 pathway [36]. And some researches also demonstrated that the anticancer effect of 5 -FU
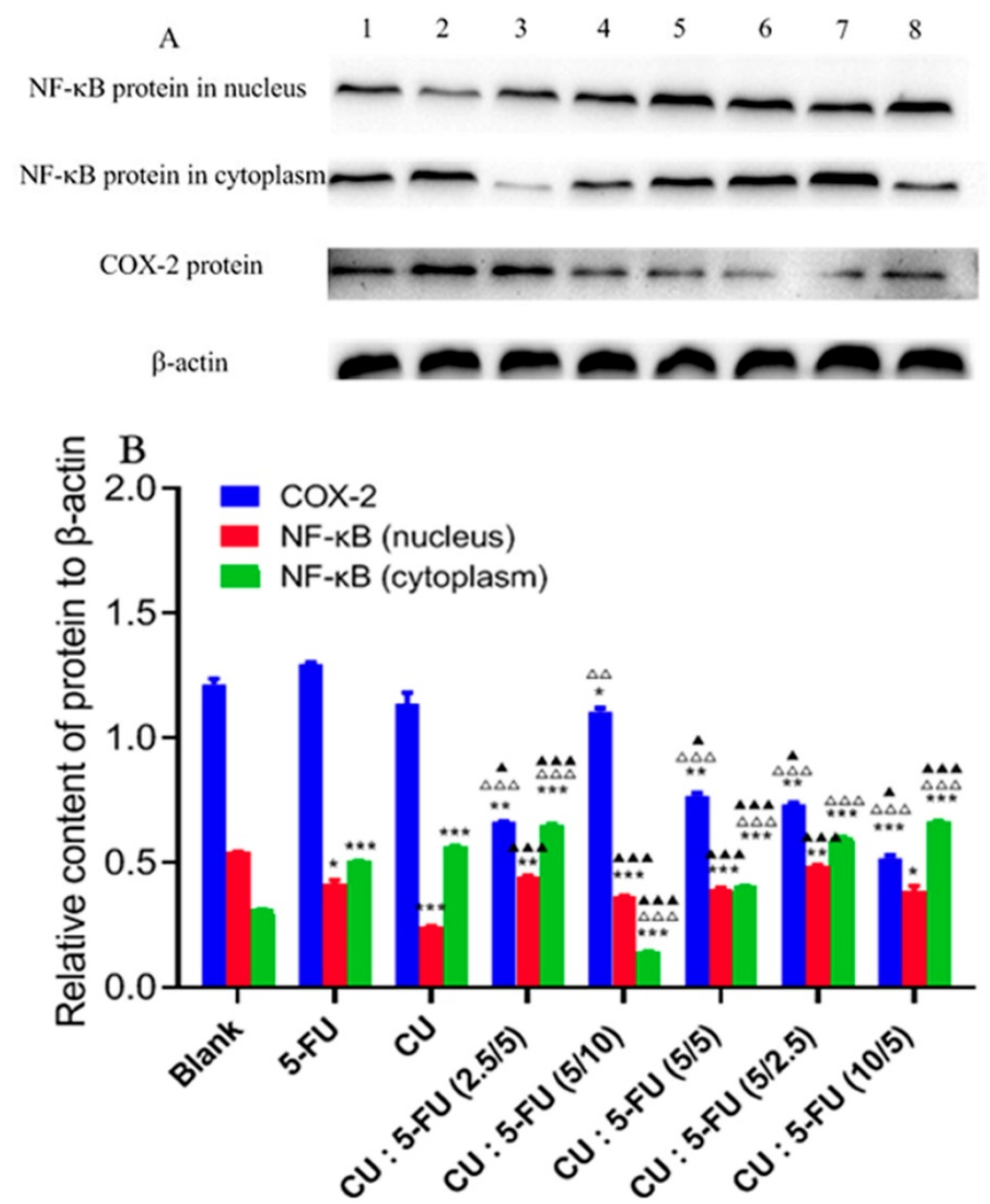

Figure 4. Effects of $\mathrm{CU}$ and 5-FU alone or in combination on the protein expressions of NF-KB in nucleus, NF-KB in cytoplasm and COX-2 on SMMC-7721 cells by Western blotting analysis. SMMC-7721 cells were treated with CU and 5-FU alone or in combination for $48 \mathrm{~h}$. A: Band 1 was $15 \mu \mathrm{mol} / \mathrm{L}$ of 5 -FU; Band 2 was $25 \mu \mathrm{mol} / \mathrm{L}$ of $\mathrm{CU}$; Band 3 was $5 \mu \mathrm{mol} / \mathrm{L}$ of $\mathrm{CU}+10 \mu \mathrm{mol} / \mathrm{L}$ of $5-\mathrm{FU}$; Band 4 was $5 \mu \mathrm{mol} / \mathrm{L}$ of $\mathrm{CU}+5 \mu \mathrm{mol} / \mathrm{L}$ of $5-\mathrm{FU}$; Band 5 was $5 \mu \mathrm{mol} / \mathrm{L}$ of $\mathrm{CU}+2.5 \mu \mathrm{mol} / \mathrm{L}$ of $5-\mathrm{FU}$; Band 6 was $10 \mu \mathrm{mol} / \mathrm{L}$ of CU $+5 \mu \mathrm{mol} / \mathrm{L}$ of 5 -FU; Band 7 was $2.5 \mu \mathrm{mol} / \mathrm{L}$ of $\mathrm{CU}+5 \mu \mathrm{mol} / \mathrm{L}$ of 5 -FU; Band 8 was blank group. B: NF-KB and COX-2 protein expression in low- and high-concentration groups. The results are representative of at least three independent experiments run in triplicate and expressed as the means $\pm \mathrm{SEM}$. *P $>0.05$ vs. the 5 -FU group; $\mathrm{P}<0.05$ vs. groups among groups. *, $\mathrm{p}<0.05$, **, $\mathrm{p}<0.01$, and ***, $\mathrm{p}<0.001$, compared to the blank group; $\Delta, \mathrm{p}<0.05, \Delta \Delta, \mathrm{p}<0.01$, and $\Delta \Delta \Delta, \mathrm{p}<0.001$, compared to the 5-FU alone group; $\boldsymbol{\Delta}, \mathrm{p}<0.05, \boldsymbol{\Delta} \boldsymbol{\Delta}$, $\mathrm{p}<0.01$, and $\boldsymbol{\Delta} \boldsymbol{\Delta} \boldsymbol{\Delta}, \mathrm{p}<0.001$, compared to the $\mathrm{CU}$ alone group. 

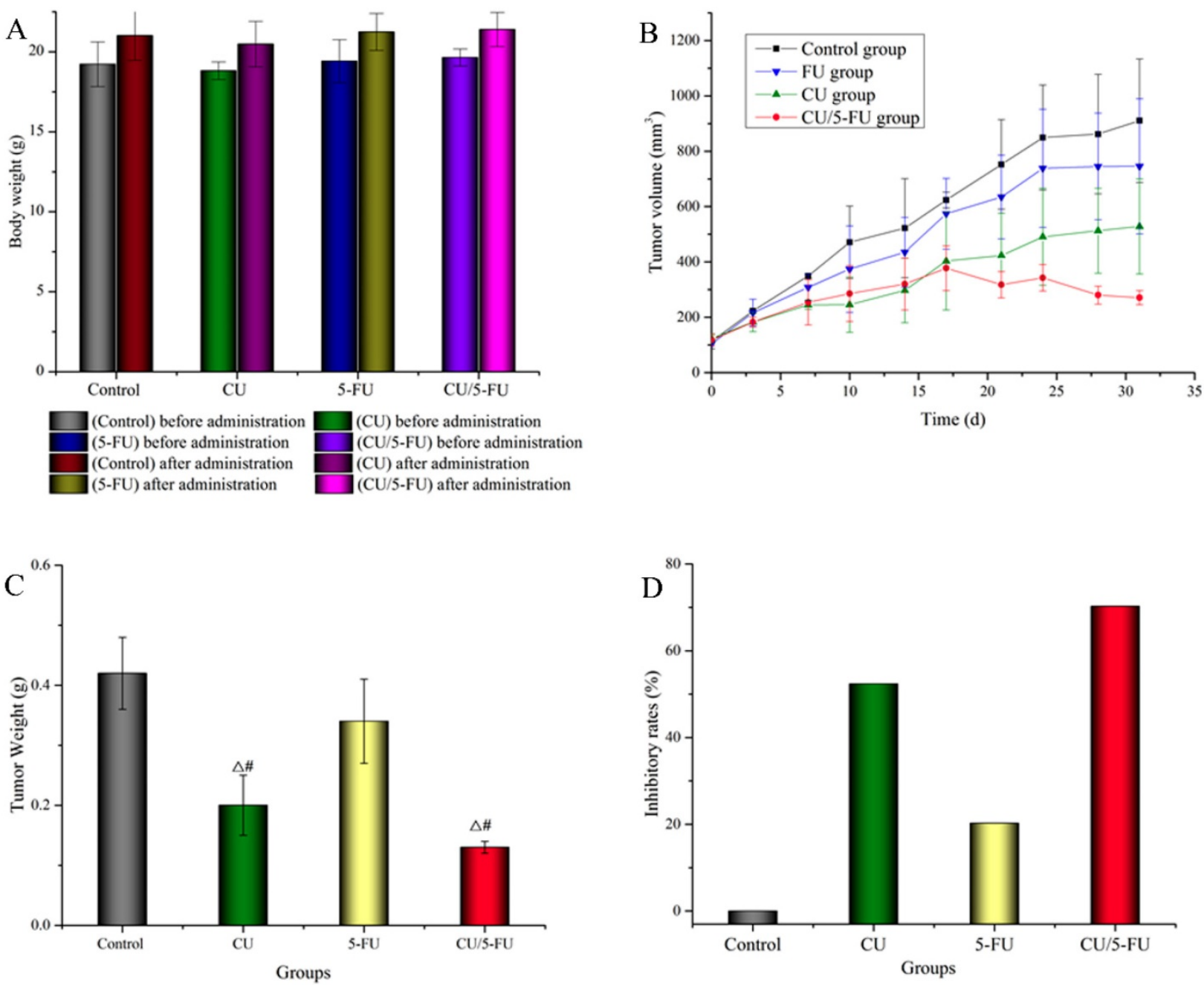

Figure 5. Antitumor efficacy and toxicity of $\mathrm{CU}$ and 5-FU alone or in combination in nude mice bearing SMMC-7721 tumor xenografts in vivo. A: The changes of body weight $(\mathrm{g})$ before and after treated with $\mathrm{CU}$ and 5 -FU alone or in combination in nude mice; B: The changes of tumor volume with different groups in nude mice; $\mathrm{C}$ : Tumor weight ( $\mathrm{g}$ ) of 7721 -bearing nude mice treated with CU and 5-FU alone or in combination on day 31 st when the mice were humanely sacrificed (mean \pm SD). Note: T-test, ${ }^{\triangle} P<0.05$ vs. the control negative group; $\# P<0.05$ vs. the 5 -FU group; D: Tumor inhibitory rates (\%) of 7721-bearing nude mice treated with 5-FU and CU alone or in combination on day 31 st.

against cancers could be enhanced by $\mathrm{CU}$ via down-regulation of COX-2 and NF-kB pathways [37, 38]. Therefore, it may be an ideal strategy to use the combination of $\mathrm{CU}$ and 5-FU to treat HCC.

In this study, we evaluated the cytotoxic effect of 5 -FU and $\mathrm{CU}$ alone or in combination with a various concentrations of 5-FU $(6.25-200.00 \mu \mathrm{mol} / \mathrm{L})$ and $\mathrm{CU}$ $(6.25-200.00 \mu \mathrm{mol} / \mathrm{L})$ against SMMC-7721 and Bel-7402 cells for $48 \mathrm{~h}$ drug exposure by MTT assay. The results demonstrated that the combination of 2:1 group showed stronger inhibitory effect on SMMC-7721 cells than that of 5-FU and CU alone with 10.1- and 20.6-fold increased cytotoxicity for $48 \mathrm{~h}$ treatment, respectively (Figure 1 \& Table 1). And 2:1 group also showed the strongest synergistic effect in SMMC-7721 cells. Furthermore, the data were consistent with previous research that combination of SLN-curcumin and LDH-5-FU exhibited synergistic cytotoxic effects against SMMC-7721 cells [39]. So these results indicated that combination administration of CU and 5-FU in certain proportional region may be a potent therapeutic regimen to treat HCC.

Study had shown that inhibiting the expression of NF-KB and COX-2 protein could increase the sensitivity of HCC and gastric cancer cells to chemotherapeutic drugs [40]. In this research, the molar ratio (2:1) groups showed strongest inhibition of COX-2 in SMMC-7721 cells with statistical significance $(\mathrm{P}<0.05)$ (Figure $4 \mathrm{~B})$. Namely, 2:1 group inhibited the expressions of COX-2 compared to 5-FU alone and blank group with 50-60\% inhibition whether in high or low concentration group, which was consistent with previous cytotoxicity studies. In addition, inhibiting NF-kB transferring from cytoplasm to nucleus can also improve the apoptosis of HCC cells. 2:1 group showed the great effect in decreasing the expression of NF-kB in the nucleus and 
increasing the expression of NF- $\mathrm{KB}$ in cytoplasma with concentration depending on SMMC-7721 cells (Figure 4B). Therefore, the greater inhibition of the combination of 2:1 group in SMMC-7721 cells compared to single drug alone may contribute, at least in part, to the inhibition of the expressions of COX-2 and NF-kB proteins.

To assess the synergistic effect of combination treatment against HCC in vivo, we examined whether the group of CU and 5-FU $(2: 1, \mathrm{~mol} / \mathrm{mol})$ inhibited the growth of the tumor of SMMC-7721-bearing nude mice. Before the experiment, the solvent used in the research was selected. Considering that $\mathrm{CU}$ was insoluble in water, proper solubilizer should be added to the solvent. Tween 80 and polyoxyethylene castor oil (EL) were the common solvents in injection. However, Tween 80 for injection had a high risk of hemolysis and anaphylaxis. The dosage of Tween 80 for injection was $0.5-1.0 \%$ but with low safety $[41,42]$. The most common and serious adverse reaction was complement activation-related pseudoallergy (CARPA), an acute hypersensitivity reaction, but CARPA could be slowly reduced or even disappeared over time [43, 44] Taxol, a paclitaxel injection, has been put into use in clinic. Its solvent was EL and absolute ethanol $(1: 1, \mathrm{v} / \mathrm{v})$ [45]. 5-FU in clinical application was dissolved in the sterile solution prepared by sodium chloride injection which adjusted $\mathrm{pH}$ with sodium hydroxide. So we investigated the dissolution of $\mathrm{CU}$ and 5-FU in the solution which adjusted $\mathrm{pH}$ with sodium hydroxide or sodium bicarbonate. The results showed that adjusting $\mathrm{pH}$ to weak alkalinity had no significant effect on the solubility of CU and 5-FU, and the solubility of drugs could not meet the dosage required in this study. After comprehensive consideration, EL-35: black absolute ethanol: sodium chloride injection (1:1:2, $\mathrm{v} / \mathrm{v} / \mathrm{v}$ ) was used as the solvent to dissolve CU and 5-FU to reach the desired concentration. And the pre-experiments showed that nude mice had good tolerance to this injection. After the experiment, the weight of mice did not decrease (Figure 5A). The volumes (Figure 5B) of SMMC-7721 tumors in mice treated with vehicle, $\mathrm{CU}$ or 5-FU alone were gradually increased with time increase. However, the tumor volume in mice treated with $\mathrm{CU}$ plus $5-\mathrm{FU}$ was decreased. In addition, the results of tumor weight (Figure 5C) and tumor inhibition rate (Figure 5D) also showed that the effect of combination was stronger than that of single and control group. The results of pharmacodynamics in vivo were in agreement with that of cytotoxicity in vitro, which indicated that the combination of CU and 5-FU $(2: 1, \mathrm{~mol} / \mathrm{mol})$ showed synergistic effect in inhibiting HCC.

\section{Conclusion}

In conclusion, the combination of $\mathrm{CU}$ and 5-FU showed obvious synergistic effect in a certain proportion including 1:1, 1:2, 2:1 and 4:1 (ratios of CU and 5-FU) on SMMC-7721 cells. Among them, the optimal ratio of combined anti-hepatocellular carcinoma was 2:1 $(\mathrm{CI}<0.3)$. And the 2:1 group also showed excellent effect on inhibiting the growth of tumors in the nude mice with SMMC-7721 subcutaneous tumors, which was consistent with the results of in vitro experiments. The mechanism of that may be related to the inhibition of the expression of COX-2 and the reducing the transfer of NF- $\mathrm{kB}$ from cytoplasm to nucleus.

\section{Acknowledgements}

This study was financially supported by the Science and Technology Fund for Distinguished Young Scholars of Sichuan Province (No. 2017JQ0013), the Joint Fund of Luzhou City and Southwest Medical University (No. 2017LZXNYD-T02, 2019LZXNYDZ07], the Science and Technology Fund of Luzhou City (No. 2019-SYF-35), Science and Technology Innovation Team from Jiucheng Science and Technology Talent Cultivation Plan in Luzhou City (2019-1)), the Scientific Research Foundation of the Education Department of Sichuan Province (No. 17ZA0439, 18ZB0646), the Joint Fund of Sichuan Province, Luzhou City and Southwest Medical University (No. 14JC01343-LH59), the research grant from Traditional Chinese Medicine Administration in Sichuan Province (2018QN069), the research grant from National and Sichuan province Innovative Entrepreneurship Training Program For Undergraduates (No. 2017-10632016, 2017-10632018).

\section{Competing Interests}

The authors have declared that no competing interest exists.

\section{References}

1. Fang J Y, Wu K S, Zeng Y, et al. Liver Cancer Mortality Characteristics and Trends in China from 1991 to 2012. Aslan Pac J Cancer P. 2014; 16:1959-1964.

2. Chen C J, Yu M W, Liaw Y F. Epidemiological characteristics and risk factors of hepatocellular carcinoma. J Gastroenterol Hepatol. 2010; 12: S294-S308.

3. Julius B, Iii V D, Asham E H, et al. Hepatocellular carcinoma: a review. Journal of Hepatocellular Carcinoma. 2016; 3: 41-53.

4. Ghouri Y A, Mian I, Rowe J. Review of hepatocellular carcinoma: Epidemiology, etiology, and carcinogenesis. Journal of Carcinogenesis. 2017; 16: 1 .

5. Zhu R X, Seto W K, Lai C L, et al. Epidemiology of Hepatocellular Carcinoma in the Asia-Pacific Region. Gut and Liver. 2016; 10: 332-339.

6. Parviz F, Abbas D, Nagy N, et al. Repetitive chemoembolization of hypovascular liver metastases from the most common primary sites. Future Oncol. 2013; 9: 419-426.

7. Penchev D K, Vladova L V, Zashev M Z, et al. Distant Liver Metastases as a Major Factor Influencing Survival in Patients with Colorectal Cancer. Nephron Clin Pract. 2016; 58: 182-187.

8. Krishnan S, Dawson L A, Seong J, et al. Radiotherapy for Hepatocellular Carcinoma: An Overview. Ann Surg Oncol. 2008; 15: 1015-1024. 
9. Liu S T, Su K Q, Zhao W X. Compound Kushen injection combined with chemotherapy in the treatment of gastric cancer: a meta-analysis of randomized controlled trials. TMR Cancer. 2019; 2: 118-126.

10. Akirov A, Larouche V, Alshehri S, et al. Treatment Options for Pancreatic Neuroendocrine Tumors. Cancers. 2019; 11: 828.

11. Salvia A L, Partelli S, Tampellini M, et al. Management of hepatic metastases of well/moderately differentiated neuroendocrine tumors of the digestive tract. Metastasis and treatment of cancer. 2016; 2: 294-303.

12. Chang $\mathrm{C} T$, Ho T $Y$, Lin $\mathrm{H}$, et al. 5-Fluorouracil Induced Intestinal Mucositis via Nuclear Factor- $\mathrm{KB}$ Activation by Transcriptomic Analysis and In Vivo Bioluminescence Imaging. PloS One. 2012; 7: e31808.

13. Garg M B, Lincz L F, Adler K, et al. Predicting 5-fluorouracil toxicity in colorectal cancer patients from peripheral blood cell telomere length: a multivariate analysis. Brit J Cancer. 2012; 107: 1525-1533.

14. Deng L F, Wang Y H, Jia Q A, et al. [Anti-proliferation effect of sorafenib in combination with 5-FU for hepatocellular carcinoma in vitro: antagonistic performance and mechanism.]. Zhonghua gan zang bing za $\mathrm{zhi}=$ Zhonghua ganzangbing zazhi $=$ Cn J Hepatol. 2013; 21: 845-849.

15. Antitumor effect of Huaier combined with 5-Florouracil in human cholangiocarcinoma cells. BMC Complement Altern Med. 2019; 19: 203.

16. Boueroy P, Hahnvajanawong C, Boonmars T, et al. Synergistic Effect of Forbesione From Garcinia hanburyi in Combination with 5-Fluorouracil on Cholangiocarcinoma. Aslan Pac J Cancer P. 2017; 18: 3343-3351.

17. Maheshwari R K, Singh A K, Gaddipati J, et al. Multiple biological activities of curcumin: A short review. Life Sci. 2006; 78: 2081-2087.

18. Mukhopadhyay A, Bueso-Ramos C, Chatterjee D, et al. Curcumin downregulates cell survival mechanisms in human prostate cancer cell lines. Oncogene. 2001; 20: 7597-7609.

19. Pillai G R, Srivastava A S, Hassanein T I, et al. Induction of apoptosis in human lung cancer cells by curcumin. Cancer Lett. 2004; 208: 0-170.

20. Elsharkawy A M, Mann D A. Nuclear factor-kappaB and the hepatic inflammation-fibrosis-cancer axis. Hepatology. 2010; 46: 590-597.

21. Muriel P. NF-KB in liver diseases: A target for drug therapy. J Appl Toxicol. 2009; 29: 91-100.

22. Ji D G, Guan $L, Y$, Luo $X$, et al. Inhibition of MALAT1 sensitizes liver cancer cells to 5 -flurouracil by regulating apoptosis through IKKa/NF-KB pathway. Biochem Bioph Res Co. 2018; 501: 33-40.

23. Vaiopoulos A G, Kalliopi Ch. Athanasoula. NF-kB in colorectal cancer. J Mol Med. 2013; 91: 1029-1037.

24. Luo J L, Kamata H, Karin M. The anti-death machinery in IKK/NF-kappaB signaling. J Clin Immunol. 2005; 25: 541-550.

25. Raharjo S J, Mahdi C, Nurdiana N, et al. Binding Energy Calculation of Patchouli Alcohol Isomer Cyclooxygenase Complexes Suggested as COX-1/COX-2 Selective Inhibitor. Advances in Bioinformatics. 2014; 2014: $1-12$.

26. Arreaza A J, Rivera H, María Correnti. Expression of COX-2 and bcl-2 in oral lichen planus lesions and lichenoid reactions. ecancermedicalscience. 2014; 8: $411-418$

27. Tang X. Cyclooxygenase-2 overexpression inhibits death receptor 5 expression and confers resistance to tumor necrosis factor-related apoptosis-inducing ligand-induced apoptosis in human colon cancer cells. Cancer Res. 2002; 62: 4903-4908

28. Yang Y, Zhu J, Gou H, et al. Clinical significance of Cox-2, Survivin and Bcl-2 expression in hepatocellular carcinoma (HCC). Med Oncol. 2011; 28: 796-803.

29. Koo, Young J, Kim H J. Curcumin inhibits the growth of AGS human gastric carcinoma cells in vitro shows synergism with 5-fluorouracil. J Med Food. 2004; 7: 117-121

30. Cao S Q, Yin T Y, Yang S L. Reversing Effects of Curcumin on Multi-drug Resistance of Bel7402/5-Fu Cell Line. Chinese Journal of Integrated Traditional and Western Medicine. 2012; 32: 244-247.

31. Du B, Jiang L, Xia Q, et al. Synergistic Inhibitory Effects of Curcumin and 5-Fluorouracil on the Growth of the Human Colon Cancer Cell Line HT-29. Chemotherapy. 2006; 52: 23-28.

32. Takeda T, Sasaki R, Nakamura A, et al. Evaluation of Paclitaxel Nanocrystals In Vitro and In Vivo. Drug Res. 2018; 68: 205-212

33. Fei G, Xiaolin Y, Rongqin M, et al. STARD13 is positively correlated with good prognosis and enhances 5 -FU sensitivity via suppressing cancer stemness in hepatocellular carcinoma cells. OncoTargets Ther, 2018, 11:5371-5381.

34. Kim D W, Talati C, Kim R. Hepatocellular carcinoma (HCC): beyond sorafenib chemotherapy. J Gastro Oncol. 2017; 8: 256-265.

35. Huang T, Zhao J, Guo D, et al. Curcumin mitigates axonal injury and neuronal cell apoptosis through the PERK/Nrf2 signaling pathway following diffuse axonal injury. Neuroreport. 2018; 29: 661-677.

36. Yu J, Zhou X, He X, et al. Curcumin Induces Apoptosis Involving bax/bcl-2 in Human Hepatoma SMMC-7721 Cells. Aslan Pac J Cancer P. 2011; 12: 1925-1929.

37. Hongru Y, Shaoqiu H, Yumeng W, et al. Curcumin Enhances the Anticancer Effect Of 5-fluorouracil against Gastric Cancer through Down-Regulation of COX-2 and NF- кB Signaling Pathways. J Cancer. 2017; 8: 3697-3706.

38. Wei $Y$, Yang $P$, Cao S, et al. The combination of curcumin and 5-fluorouracil in cancer therapy. Arch Pharm Res. 2018; 41: 1-13.

39. Zhu R, Wu X, Xiao Y, et al. Synergetic Effect of SLN-Curcumin and LDH-5-Fu on SMMC-7721 Liver Cancer Cell Line. Cancer Biother Radio. 2013; 28 . $579-587$
40. Hao J, Li Z, Zhang C, et al. Targeting NF-кB/AP-2 $\beta$ signaling to enhance antitumor activity of cisplatin by melatonin in hepatocellular carcinoma cells. Am J Cancer Res. 2017; 7: 13-27.

41. Soleymani J, Jouyban-Gharamaleki V, Suleymanov T A, et al. Solubilization of lamotrigine using Tween 80 and ethylene glycol or propylene glycol. J Mol Liq. 2017; 236: 249-253.

42. Yang R, Lao Q C, Yu H P, et al. Tween-80 and impurity induce anaphylactoid reaction in zebrafish. J Appl Toxicol. 2015; 35: 295-301.

43. Goto E, Shimazaki J, Monden Y U, et al. Low-concentration homogenized castor oil eye drops for noninflamed obstructive meibomian gland dysfunction. Ophthalmology. 2002; 109: 2030-2035.

44. Szebeni J. Complement activation-related pseudoallergy: A new class of drug-induced acute immune toxicity. Toxicology. 2005; 216: 106-121.

45. Huizing M T, Rosing H, Koopmans F P, et al. Influence of Cremophor EL on the quantification of paclitaxel in plasma using high-performance liquid chromatography with solid-phase extraction as sample pretreatment. J Chromatogr B Biomed Sci Appl. 1998; 709: 161-165. 